\title{
Research on College English Writing Teaching under the Background of Big Data: Taking Leshan Normal University as an Example
}

\author{
Xiaoping Tan \\ Leshan Normal University, Leshan, China
}

\begin{abstract}
In recent years, online education has been in the ascendant in China's education market. Among many competitors in this market, the Pigai system, an intelligent online English essay marking system based on big data analysis, is standing out from the crowd. More and more universities, colleges, even middle schools are taking advantage of it. This paper mainly introduces the reform of writing teaching model by utilizing this system in Leshan Normal University. The experiment of the teaching reform has shown that Pigai can shorten the working hours for teachers, develop students' habit of autonomous study and improve their writing motivation and good language expression ability.
\end{abstract}

Index Terms - college English, teaching of writing, teaching reform, big data, Pigai system

\section{BACKGROUND}

The popularization of Internet and various mobile devices have brought human beings into a new information age. Under such circumstances, governments and education departments in all countries, especially in developed countries, are focusing on the education informationization advancement. The United States put forward the plan of the development of educational technology in 1996, demanding all the schools be connected with Internet. In order to hold on a dominate position in education, it released National Educational Technology Planning in 2010 to reform American education and to enhance learning by technology. This planning has led to the reform of study method, assessment method and teaching method. (Chen Jiaming \& Jin Yinglian, 2012) In 2005 and 2008, the UK promulgated the five-year policy on the development of educational technology, hoping to change the form of children's learning. Students are asked to do their homework by computer or on the Internet. ( Ma Ning, Zhou Pengqin \& Xie Minyi, 2016) Denmark issued the Grand Plan of Information Technology in 2010. Germany launched the Digital Education Strategy 2030 in October 2016. (Liu Jialing, Pan Tangxian \& Kong Jing, 2017) In recent years, Korea has been practicing Ulearning based on E-learning, inspiring students to learn at any given time or place by any terminal. In 2012, the United Nations released the white paper Big Data for Development: Challenges \& Opportunities, saying that the big data era is coming. (Zhang Daoxue \& Zhao Keyun, 2017) In order to be in line with the development of the society, Ministry of Education of the People's Republic of China(2012) published Outline of National Medium-and Long-Term Program for Education Reform and Development (2010-2020) . It points out that by 2020, an education informationization system covering schools at all levels in urban and rural areas will have been basically established to promote the modernization of teaching content and teaching methods. As we can see, every country is paying attention to the development of educational technology. Traditional methods of teaching, studying and assessing can no longer meet the need for talent training in this new age. Therefore, a new reform of education is in desperate need. Teachers should improve their ability of applying information technology, update their teaching concepts and refine their teaching methods to improve their teaching quality. At the same time, students should be encouraged to study actively and independently and enhance the ability to use information technology to analyze and solve problems with informationized methods. Informatization and big data are providing new opportunities for modern education. "The era of big data has brought great changes in the theories and practices of the teaching of college English writing, specifically in such areas as teaching resources, writing objectives, writing content and structures, writing aids and tools, writing evaluation and connotation of writing ability." (Wang Haixiao, 2014) In the face of this new situation, how to make full use of modern information technology to carry out the reform in college English teaching is an issue that every teacher should take into consideration.

\section{INTRODUCTION OF THE PIGAI SYSTEM}

The Pigai system (located at https://www.pigai.org/) is the first intelligent marking system for English writing in China based on big data, which can assess each essay within 1.2 seconds averagely by generating a report, including overall score, comments and sentence-by-sentence feedback. It can be applied to all English writing skills and requirements due to its efficiency and brilliance based on its huge standard English language corpus and the strong 
192-dimension scoring technology. Needless to say, the system can point out the English learners' Chinglish and at the same time recommend the appropriate native English expression. The Pigai system, introduced in 2011, a commercial online assessment platform, specifically developed for Chinese ESL learners, has become the largest subscribed AWE system in China and has served more than 20 million users, and over 6000 schools and universities in China, having assessed more than 430 million essays. The system offers the online automatic essay marking service in the form of SAAS service. Teachers and students can get access to it just by visiting its website, needless to install any software as long as network is available. Pigai provides teachers and students with different web-pages. Teachers and students can use the Pigai system according to the following steps:

1. The teacher registers an account with e-mail address;

2. The teacher assigns writing tasks in the Pigai system;

3. The student registers an account with e-mail address;

4. The student submits his essays on the website;

5. Pigai corrects students' essays and generates their personalized feedback automatically;

6. The teacher analyzes students' writing data provided by Pigai.

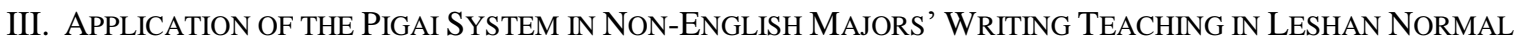 UNIVERSITY}

Due to the large size of the class, the college English teachers in Leshan Normal University shoulder heavy tasks: each teacher has more than 16 class hours per week on average, deliver courses for at least 6 classes containing about 300 students on average per semester, and for some teachers, the number of the students even reaches 500.Traditionally, college English teachers can only correct students' essays once a semester because of the inefficiency of off-line writing and the large quantity of correcting tasks. Moreover, from teacher's rough correction, students can hardly find their specific problems in writing and cannot get detailed suggestion from their teachers, so they lack the motivation to revise their essays over and over again and therefore, make slow improvement in English writing skills. In order to change the situation, we have been struggling to find a new way to teach writing. As soon as Pigai came out in 2011, it became our best choice. Students are required to complete at least 5 essays each semester in the Pigai system. The average score of the 5 tasks serves as part of the student's writing scores for the semester and makes up a portion of student's final exam scores, accounting for $20 \%$.

Around seven years has passed since the teachers and students in Leshan Normal University got registered and began to use the Pigai system in 2012. The number of users has increased sharply year by year. From January 2013 to January 2018, 147 teachers and 29870 students of Leshan Normal University registered and made use of Pigai, and the students submitted 307168 essays (Among which 290935 compositions were assigned by the teachers). Various data have been collected as follows.

TABLE 1.

USER USAGE REPORT FROM JANUARY 2013 TO SEPTEMBER 2018

\begin{tabular}{|c|c|c|c|c|}
\hline Time & $\begin{array}{c}\text { The number of } \\
\text { teachers }\end{array}$ & $\begin{array}{c}\text { The number of } \\
\text { assigned essays }\end{array}$ & $\begin{array}{c}\text { The number of students who } \\
\text { submitted essays }\end{array}$ & $\begin{array}{c}\text { The number of submitted } \\
\text { essays }\end{array}$ \\
\hline Jan.2013 & 10 & 30 & 459 & 1848 \\
\hline Jan. 2014 & 70 & 240 & 7825 & 32732 \\
\hline Jan.2015 & 89 & 487 & 12879 & 81887 \\
\hline Jan. 2016 & 109 & 796 & 17925 & 136578 \\
\hline Jan. 2017 & 125 & 1100 & 22898 & 193217 \\
\hline Jan. 2018 & 147 & 1835 & 29870 & 307168 \\
\hline
\end{tabular}

The number of assigned essays

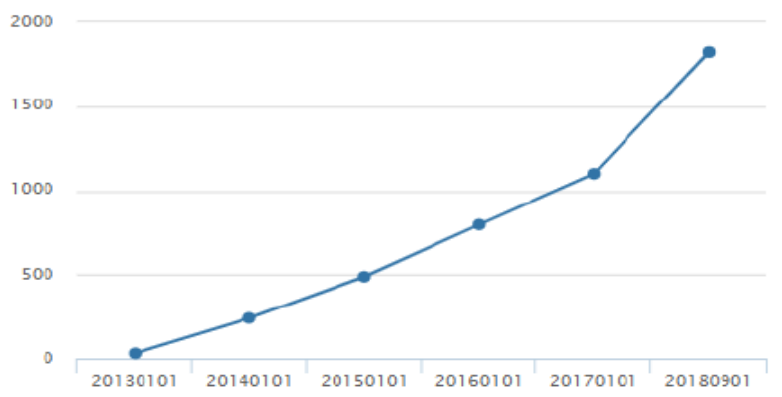

The number of submitted essays

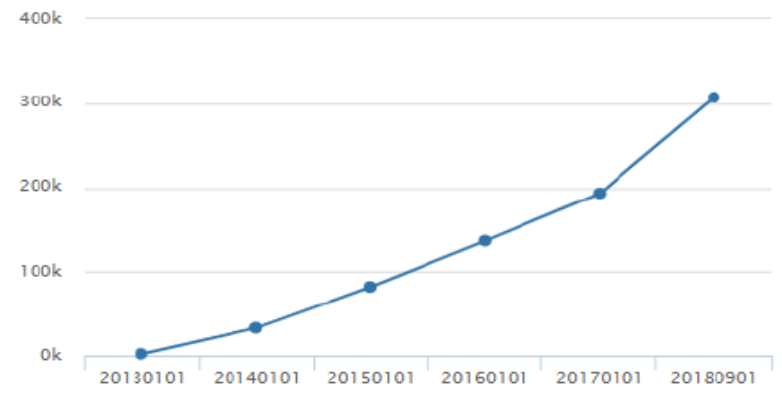

Figure 1. The Number of Essays Assigned and Submitted 


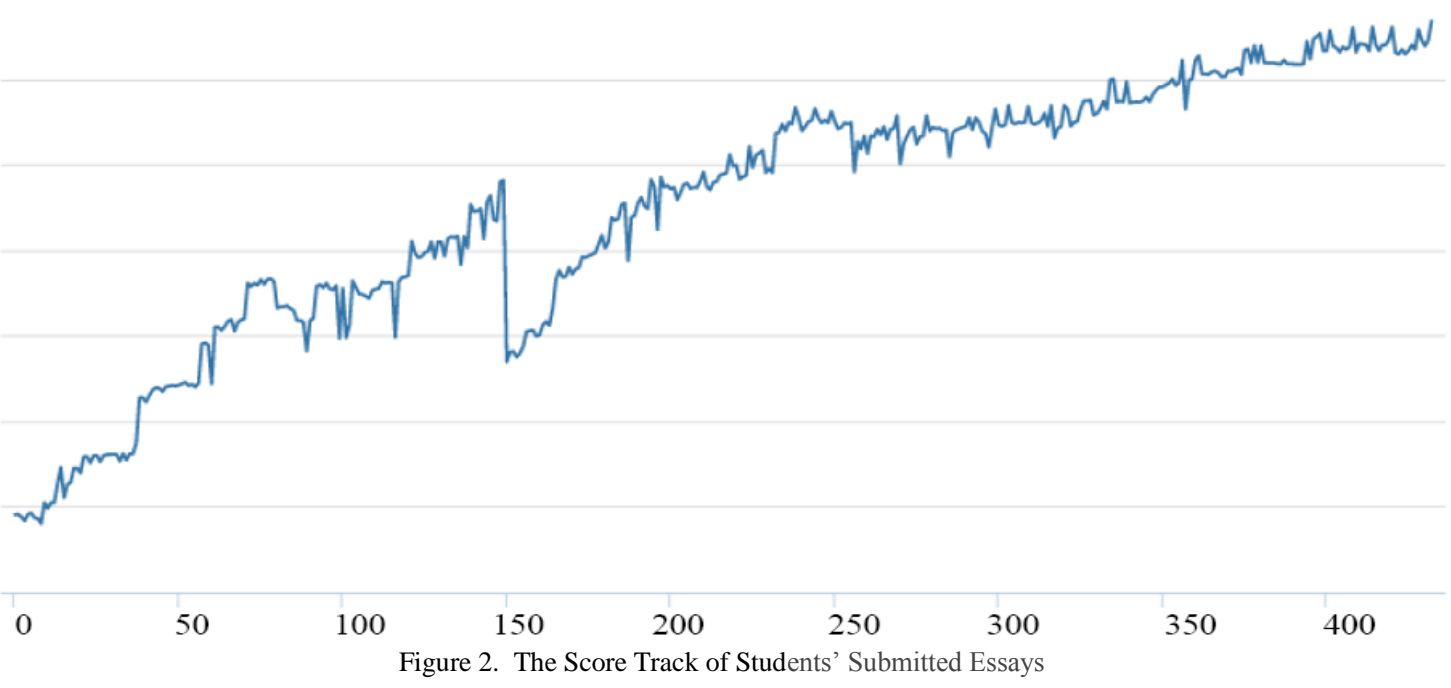

TABLE 2.

The Net Annual Growth of Using the the Pigai System In LeShan Normal UniVERsity

\begin{tabular}{|l|c|c|c|c|c|c|c|}
\hline \multicolumn{1}{|c|}{ Year } & 2012 & 2013 & 2014 & 2015 & 2016 & 2017 & 2018 \\
\hline Project & & & & & \\
\hline $\begin{array}{l}\text { The total number of } \\
\text { student registration }\end{array}$ & 467 & 7426 & 5073 & 5066 & 4989 & 6225 & 29870 \\
\hline $\begin{array}{l}\text { The total number of } \\
\text { teacher registration }\end{array}$ & 10 & 70 & 89 & 109 & 125 & 142 & 147 \\
\hline $\begin{array}{l}\text { The number of active } \\
\text { student users number of }\end{array}$ & 426 & 7159 & 9867 & 10714 & 11367 & 13158 & 172578 \\
\hline $\begin{array}{l}\text { The } \\
\text { active teacher users }\end{array}$ & 34 & 34 & 44 & 46 & 48 & 910 \\
\hline $\begin{array}{l}\text { The total number of } \\
\text { titles of assigned essays }\end{array}$ & 30 & 208 & 244 & 307 & 304 & 448 & 1835 \\
\hline $\begin{array}{l}\text { The total number of } \\
\text { submitted essays }\end{array}$ & 1847 & 30884 & 49154 & 54685 & 56645 & 73196 & 307168 \\
\hline $\begin{array}{l}\text { The total number of } \\
\text { manual corrections }\end{array}$ & 6 & 2222 & 968 & 1477 & 1209 & 2072 & 9498 \\
\hline $\begin{array}{l}\text { The total number of } \\
\text { corrections by machine }\end{array}$ & 10318 & 279633 & 506781 & 603516 & 689451 & 646418 & 2742423 \\
\hline
\end{tabular}

\section{Usage of Pigai by Teachers}

147 teachers assigned 1,835 writing topics and received 307,168 compositions from their students, with an average of 12.48 topics assigned by each teacher. For each topic an average of 167.39 compositions were submitted.

The number of the teachers who has more than 40 students is 62 , covering 42.18 percent of the teacher users.

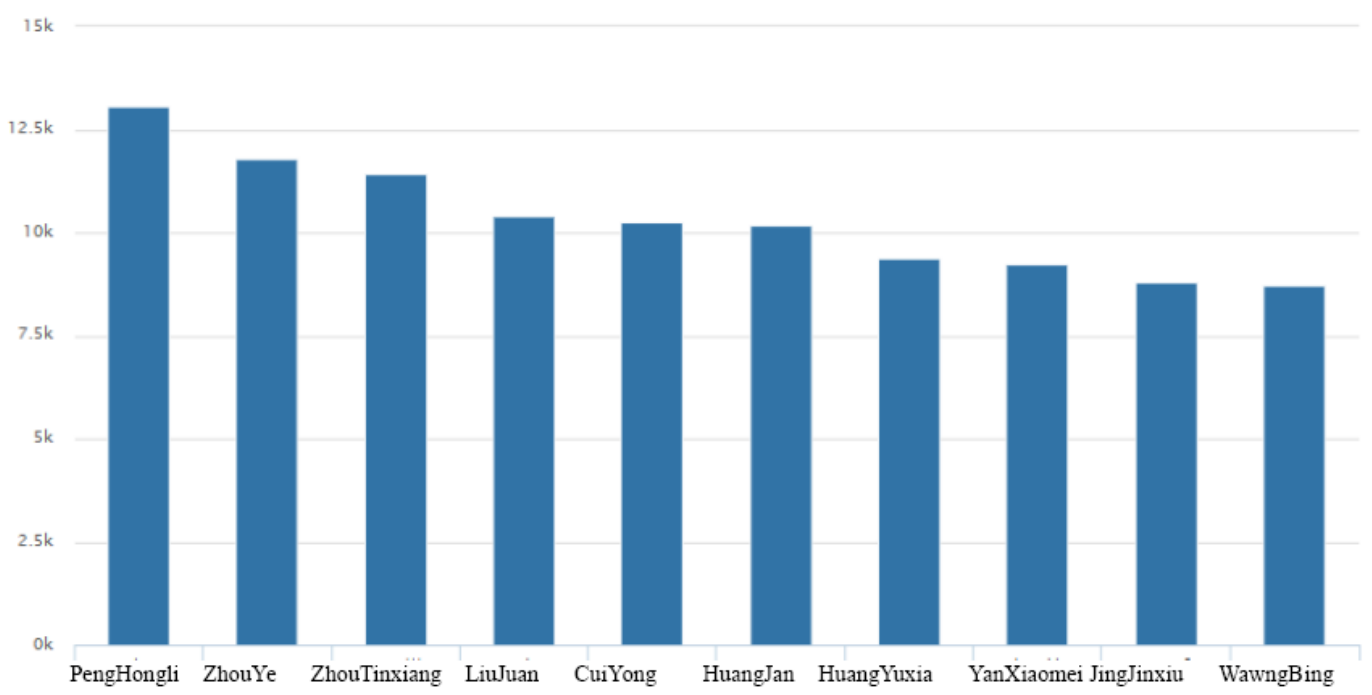
Figure 3. The Top Ten Teachers Whose Students' Revision Work Ranks in Top Ten 


\section{Usage of Pigai by Students}

Of the 2,9870 registered students, 27,375 submitted compositions assigned by the teachers, accounting for 91.84 of the total number of registered students;

The students have submitted 307,168 compositions (Among them, 29,0935 compositions were assigned by teachers and 16,233 compositions were written and submitted by students themselves.);

The students revised their compositions 2742423 times, with an average of 8.928 times of revision for each composition;

The highest revision record of students' compositions is 433 times (The student's name:Liu Yi ; Student Number: 1626140422; His teacher's name : Peng Hongli ; Composition Number: 737526).

TABLE 3.

THE TOP 10 STUDENTS FOR THE NUMBER OF REVISIONS FROM JANUARY, 2012 TO SEPTEMBER, 2018

\begin{tabular}{|c|c|c|c|c|c|c|c|c|}
\hline No & Name of the Student & frequency & Unique ID & Essay ID & $\begin{array}{c}\text { Name of the } \\
\text { Teacher }\end{array}$ & $\begin{array}{c}\text { Initial } \\
\text { Score }\end{array}$ & $\begin{array}{c}\text { Final } \\
\text { Score }\end{array}$ & $\begin{array}{c}\text { Growth } \\
\text { Fraction }\end{array}$ \\
\hline 1 & Liu Yi & 433 & 38980498 & 737526 & Peng Hongli & 59.5 & 88.5 & 29 \\
\hline 2 & He Li & 355 & 25995408 & 496231 & Xie Lisha & 58.4 & 83 & 24.6 \\
\hline 3 & Gu Youchen & 341 & 22649917 & 506907 & Yan Gaorong & 46.1 & 89.8 & 43.7 \\
\hline 4 & Fang Jing & 333 & 11747203 & 375034 & Song Yusi & 48.8 & 79.8 & 31 \\
\hline 5 & Zhao Yili & 322 & 8357558 & 331187 & Tan Xiaoping & 66 & 85 & 19 \\
\hline 6 & Yu Guangrong & 310 & 18511673 & 456002 & Wei Ningling & 83 & 92 & 9 \\
\hline 7 & Liang Zheng & 288 & 10861735 & 363331 & Wang Bing & 47.8 & 83.1 & 35.3 \\
\hline 8 & Chen Wei & 277 & 42565686 & 774860 & Zhang Yin & 32.6 & 82.1 & 49.5 \\
\hline 9 & Luo Suya & 252 & 63206425 & 1032393 & Xu Yilan & 49.1 & 81.4 & 32.3 \\
\hline 10 & Cai Qin & 243 & 22040902 & 496256 & Xie Lisha & 61.6 & 76.7 & 15.1 \\
\hline
\end{tabular}

The Original Manuscript Submitted for the First Time(59.5 points)

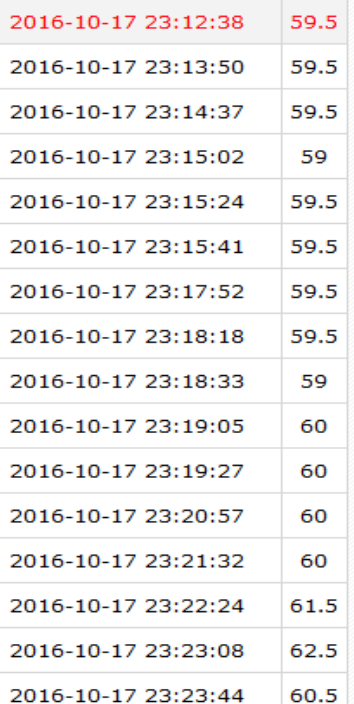
Figure 4. The Top Record of Revision------LIU Yi Revised a Single Essay for 433 Times.

\section{The 47th Revision Scoring 67}

\begin{tabular}{|l|l|l|}
\hline 46 & $2016-10-1723: 47: 57$ & 66.5 \\
\hline 47 & $2016-10-1723: 48: 12$ & 67 \\
\hline 48 & $2016-10-1723: 48: 25$ & 67 \\
\hline 49 & $2016-10-1723: 48: 39$ & 67 \\
\hline 50 & $2016-10-1723: 48: 51$ & 67 \\
\hline 51 & $2016-10-1723: 49: 12$ & 67 \\
\hline 52 & $2016-10-1723: 49: 29$ & 67 \\
\hline
\end{tabular}

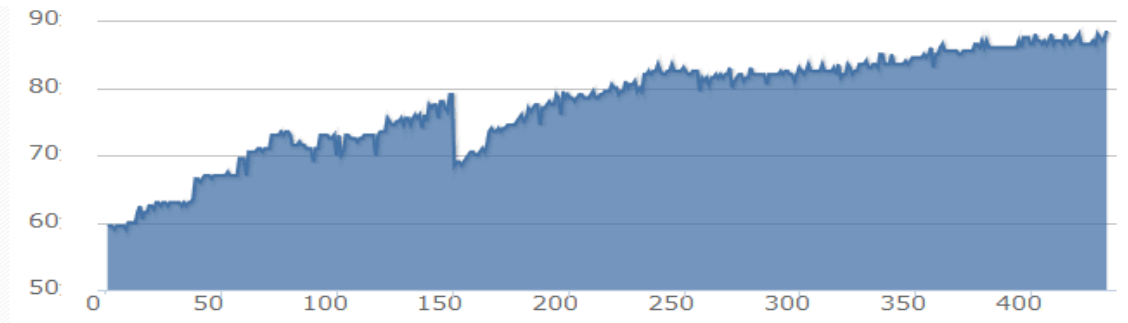

In our life,we will meet many important people.Such as

teachers, classmates, colleagues.Some of those people, we will make friends with them. I think friends are important in our life. They give us help like our parents. They never ask for repayments.They often share happiness with us.When we sad, they will company with us or give us a hug. When we are in trouble,they will help us out.

My best friend is in other city,but our friendship don't change. We don't meet each other long time.I miss her very much.I want to play with her.I hope I can have a chat and have lunch with her on holiday.

A friend inneed is a friend indeed.I am glad to have such a friend.I hope I can have more true friends in the future. Wealth is not our friends, while friends are our wealth.
I consider friends are important in our life. They give us help like our parents. They never request repayments. They often share happiness with us. When we are gloomy, they will company with us or else give us a hug. When we are in trouble, they will do me a favor. My best friend is in the other cities, but our friendship doesn't transform. We don't meet each other long time. I time.I miss her very much.I much. I want to play with her. I hope I can have a chat and have lunch with her on holiday.

A friend ineed is a friend indeed.I am glad to have such a friend.I hope I can have more true friends in the future. Wealth is not our friends, while friends are our wealth.

In every life stages, friends are very important for us, so we should value our friends. I wish everyone can have more true friends. 
The 104th Revision Scoring 73

\begin{tabular}{|l|l|l|}
\hline 103 & $2016-10-1821: 45: 54$ & 70.5 \\
\hline 104 & $2016-10-1821: 47: 09$ & 73 \\
\hline 105 & $2016-10-1821: 48: 08$ & 73 \\
\hline 106 & $2016-10-1821: 49: 04$ & 72.5 \\
\hline 107 & $2016-10-1821: 49: 19$ & 72.5 \\
\hline 108 & $2016-10-1821: 50: 58$ & 72.5 \\
\hline 109 & $2016-10-1821: 51: 27$ & 72 \\
\hline 110 & $2016-10-1821: 52: 29$ & 72.5 \\
\hline 111 & $2016-10-1821: 53: 31$ & 72.5 \\
\hline 112 & $2016-10-1821: 53: 47$ & 73 \\
\hline
\end{tabular}

\section{The 235th Revision Scoring 82.5}

\begin{tabular}{|l|l|c|}
\hline 233 & $2016-10-2018: 03: 43$ & 82 \\
\hline 234 & $2016-10-2018: 03: 53$ & 82 \\
\hline 235 & $2016-10-2018: 04: 30$ & 82.5 \\
\hline 236 & $2016-10-2018: 06: 03$ & 82 \\
\hline 237 & $2016-10-2018: 07: 20$ & 82.5 \\
\hline 238 & $2016-10-2018: 07: 43$ & 82.5 \\
\hline 239 & $2016-10-2018: 07: 54$ & 83.5 \\
\hline 240 & $2016-10-2018: 08: 47$ & 82.5 \\
\hline 241 & $2016-10-2018: 10: 53$ & 82 \\
\hline 242 & $2016-10-2018: 11: 56$ & 82 \\
\hline 243 & $2016-10-2018: 12: 15$ & 82.5 \\
\hline 244 & $2016-10-2018: 12: 35$ & 82.5 \\
\hline 245 & $2016-10-2018: 12: 58$ & 83.5 \\
\hline 246 & $2016-10-2018: 22: 47$ & 82.5 \\
\hline 247 & $2016-10-2018: 24: 47$ & 82.5 \\
\hline & & \\
\hline
\end{tabular}

In our life, we will meet many important characters. For example, teachers, classmates, an so on. colleagues. Some of them, we will make friends with them.

I take into account friends who are important in our life. They do me favor like our parents They never request repayments. They often share happiness with us. When we are gloom they will company with us otherwise give us a hug. When we are in trouble, they will do $\mathrm{m}$ a favor.

My best friend is in the other cities, but our friendship doesn't transform. We don't meet each other long time. I miss her more than much. I want to play with her. I hope I can hav a chat and hang out with her on holiday.

A friend in need is a friend indeed. I am glad to have such a friend. I hope I can have more true friends in the future. Wealth is not our friend, while friends are our wealth.

In our life stages, friends are more than importance for us, for that trigger we should valu our friends. I wish everyone can have more true friends.

In our life, we will meet many characters. It is just like our educators, classmates, colleagues. We will make friends with some of them, but some of them are passing travellers.

Friends are important to us. Wealth is not a friend, but a friend is a treasure.

I hold a view that we should value them. In our daily life, friends will give us more help. They will share happiness with us. When we are in trouble, they are willing to help us out. They do us a favor like our parents, and they don't ask for payback. When we are gloomy, they will company with us and give us a hug which can make us out of sorrow.

My best friend is in another city. We don't meet each other long time, but our friendship doesn't transform. I hope I can chat with her and hang out on holiday. I miss her more than much. For my standpoint our friendship will go on until we disappear.

A friend in need is a friend indeed. I am glad to have such a friend. She learns me to know what is the meaning of true friends. I hope I will have more true friends in the future. True friends for us just like water for fish. I wish everyone will have a friendship, for the trigger that it is a wonderful memory. When we are old, we will be happy to think of these memories.

When you have a true friend, you and she will improve together. Maybe your hobbies are different, but your character is similar. When you succeed, she will not be jealous, while you failed, she will comfort you. Sometimes friend is another ourselves.

Nevertheless in a friendship, you and your friend must believe in each other. Friendship requires two people individuals to work together to maintain. 
The 433rd Revision Scoring 88.5

\begin{tabular}{|l|c|c|}
\hline 418 & $2016-10-2211: 33: 44$ & 87 \\
\hline 419 & $2016-10-2211: 34: 34$ & 87 \\
\hline 420 & $2016-10-2211: 35: 00$ & 87.5 \\
\hline 421 & $2016-10-2211: 36: 56$ & 88 \\
\hline 422 & $2016-10-2211: 41: 45$ & 86.5 \\
\hline 423 & $2016-10-2211: 42: 37$ & 86.5 \\
\hline 424 & $2016-10-2211: 42: 50$ & 86.5 \\
\hline 425 & $2016-10-2211: 43: 38$ & 86.5 \\
\hline 426 & $2016-10-2211: 43: 56$ & 86.5 \\
\hline 427 & $2016-10-2211: 44: 20$ & 87 \\
\hline 428 & $2016-10-2211: 45: 35$ & 86.5 \\
\hline 429 & $2016-10-2211: 47: 25$ & 88 \\
\hline 430 & $2016-10-2211: 49: 27$ & 87.5 \\
\hline 431 & $2016-10-2211: 50: 43$ & 87 \\
\hline 432 & $2016-10-2211: 51: 58$ & 87.5 \\
\hline 433 & $2016-10-2211: 52: 45$ & 88.5 \\
\hline
\end{tabular}

travellers.

As far as I knowledge is concerned, friends who help us are important. True friends for us just like water for fish otherwise life without sunshine. Personally, we should value them. In our daily life, friends will give us more help. When we are in trouble, they are willing to help us out. They give us a hand like our parents, and they don't ask for payback. When we are gloomy, they will company with us and give us a hug which can make us out of sorrow. True friends are the ones who are always company with you no matter how the situation is. My best friend is a pretty girl who is in another city. We don't meet each other long time, but our friendship doesn't transform. I miss her more than much, consequently I often call her when she is available. For my standpoint our friendship will go on until we disappear. Wealth is not a friend, but a friend is a treasure.

Nothing in the world can delight me so much as having such a friend. She learns me to know what is the meaning of true friends. Attribute to her, I have an advantage over before.

When you have a true friend, you and she will improve together. Maybe your hobbies are different, but your character is similar. She can let you gain confidence by helping you with your lessons, while benefits you all. When you succeed, she will not be jealous, while you failed, she will comfort you.

What calls for special attention is that you and your friend must trust each other.

Friendship requires two individuals to work together to maintain. Provided that you want to get what you want, you must give:

we need friendship now that we need more care- give.

\section{REFORM OF COLLEGE ENGLISH WRITING TEACHING BASED ON THE PIGAI SYSTEM}

The Pigai system was introduced to Leshan Normal University in 2012. In recent years, we have been carrying out a reform in English writing teaching based on Pigai in our school. We have constructed a new teaching model that is concluded as "Humant-computer Combined Autonomous Writing----Peer Review for Mutual Progress----Particular Instructions on Strategies". This new writing teaching model has achieved fine effects.

\section{A. Human -computer Combined Autonomous Writing}

In our writing teaching, we make full use of the Pigai system. Teachers just log on to assign a writing task with a certain title and requirement. There are a bunch of preset titles in the Pigai system for us teachers to choose according to our teaching objectives and students' abilities. We teachers can also set tasks by ourselves and assign them to our students. In the same way, students just log on Pigai.org at anytime and anywhere via a smart-phone or computer and finish the task. The system will score the composition within one second and give revise suggestions. Then students can revise and submit their compositions repeatedly till a satisfactory result is achieved. In this process, students' personalized learning awareness and autonomous learning ability get strengthened. Gradually the students have learned to learn independently by themselves.

\section{B. Peer Review for Mutual Progress}

It is advocated that students review each other's compositions after they have finished their tasks, which is called peer review. Peer review is an embodiment of cooperative learning and a process of mutual progressing for writers and readers. Writers can receive some helpful suggestions from their readers and readers can gain some new information and ideas through evaluating other's compositions. Such a pattern will broaden their horizons, bring them some fine expressions and enrich their knowledge. (Dong Yuejun, 2016) All the students can get happiness from peer review and build up concepts of cooperation little by little. As we know, no one excels in everything all of the time. We need someone else's help. So cooperation is of great importance. Little by little, the students will learn how to co-operate in the peer review, which will benefit them quite a lot in their future life and work.

\section{Particular Instructions on Strategies}

The powerful evaluation of the Pigai system doesn't mean the reduction of teachers' responsibility and their status. On the contrary it requires more from teachers. A teacher should play his role of a guider and instructor. After AI evaluation and peer review, sometimes it is necessary for teachers to correct the students' essays by hand. For example, teachers can evaluate some typical works personally, and then in class comment on dimensions of the main idea, structure and expressions. After that teachers should instruct students on elementary knowledge of writing and train students to develop a wise writing strategy. Good writing strategies will help the students to organize their thoughts well and express them freely and smoothly. (Zhang Hong, 2017) There is no doubt that students'output quality of writing texts can be improved gradually. This is the big aim of writing teaching.

Our attempts on such a new writing teaching model has effectively inspired students' interests and enthusiasm of writing. Many students have revised their essays many times. As has been mentioned above, the top record of revision was made by a student named LIU Yi, who has revised a single essay for 433 times. (See Figure 4). By doing writing and revising again and again, our students have made great progress in English writing. In 2017, 6162 students 
participated in the 2017 Big Writing Event under One Topic and the "Pigai.org Cup" National College English Writing Contest (preliminary). In the national final, Huang Yujie, a non-English major, won the second prize out of 86 contestants from universities and colleges all around China(including top tier colleges), of whom some are English majors and some non-English majors. And our college won the prize of Best Organizers. In 2018, 7506 students took part in the "2018 Big Writing Event under One Topic". In the Third 'Pigai.org Cup' Sichuan College English Writing Contest Final, Yin Juan, also a non-English major, won the first prize. We had another two second prize winners and three third prize winners.

\section{CONCLUSION}

In a word, with the development of science and technology, big data is transforming our philosophy of education and teaching methods. Based on big data, the Pigai system boasts powerful features like overall scoring, comment, sentence-by-sentence feedback and language corpus, which has reformed the college English writing teaching model to a large extent. More precisely, it has transformed the traditional result-oriented teaching method of English writing, with more focus on the process of writing practice during which students are required to revise their essays for several times according to the feedback they get from Pigai. As a result, it has effectively aroused students'interest in writing, developed their ability of self-study and improved their writing skill. The effectiveness of learning depends on how learners are actively engaged in the learning process. The success of the Pigai system exemplifies the philosophy of engaging users in an intelligent and interactive manner. (Zhang Zhe \& Zhang Yue, 2018) In the meantime, Pigai has relieved teachers of the heavy burden of correcting students' essays. Then they can spare more time to think about the reform and improvement of writing teaching. Therefore, making use of the advantages of modern network technology to create a new teaching model which can help improve the students' autonomous writing ability, enhance their English writing proficiency, promote their writing motivation and improve their self-efficacy is an important part of college English writing teaching. (YANG Xiaoqiong \& DAI Yuncai, 2015) We believe that the Pigai System will play a more important role in the college English writing teaching. More and more teachers and students are bound to take full advantage of Pigai.

\section{REFERENCES}

[1] Chen Jiaming \& Jin Yinglian. (2012).Overview of American educational informatization. Journal of World Education, 6A, $12-18$.

[2] Dong Yuejun. (2016). A New Thought for Writing and Reading Combined High-school English Teaching. Foreign Language Teaching in Schools (School Version), 2, 54-59.

[3] Liu Jialing, Pan Tangxian \& Kong Jing. (2017). Development and Enlightenment of Educational Informatization Policy in Europe. China Information Technology Education, 12, 81-85.

[4] Ma Ning, Zhou Pengqin \& Xie Minyi. (2016).Current Situation and Revelation of Educational Informationization in UK' s Basic Education. China Educational Technology, 9, 30-37.

[5] Ministry of Education of the People's Republic of China. (2012). Outline of National Medium-and Long-Term Program for Education Reform and Development (2010-2020). Beijing: People's Education Press.

[6] Wang Haixiao. (2014). Reform in the Teaching of College English Writing in the Big Data Era. Modern Distance Education Research, 3, 66-68.

[7] YANG Xiaoqiong \& DAI Yuncai. (2015). An Empirical Study on College English Autonomous Writing Teaching Model Based on www. pigai. Org. Computer-assisted Foreign Language Education, 5, 17-23.

[8] Zhang Zhe \& Zhang Yue. (2018). Automated Writing Evaluation System: Tapping its Potential for Learner Engagement . IEEE Engineering Management Review, Vol. 46, No. 3, Third Quarter, September 2018, 29-33.

[9] Zhang Daoxue \& Zhao Keyun. (2017). Research on the Improvement of Normal University Students' Imformatizational Teaching Competence Facilitated by Big Date Digital Education, 5, 28-32.

[10] Zhang Hong. (2017). Application of Automated Writing Evaluation System in Senior High School Students' English Writing Teaching. Foreign Language Teaching in Schools( School Version), 3, 50-58.

Xiaoping Tan was born in Leshan, China in 1963. She received her B.A. degree from Sichuan Normal University, China in 1990.

She is currently a professor in the School of Foreign Languages, Leshan Normal University, Leshan, China. Her research interests include linguistics and research on college English teaching. 